\title{
NOVE SINTETIČKE (DIZAJNIRANE) DROGE
}

\author{
Shpend Haxhibeqiri ${ }^{1}$, Valdete Haxhibeqiri ${ }^{2}$ \\ ${ }^{1}$ Institut za Forenzičku Psihijatriju Kosova, Sveučilišni Klinički Centar Kosova, Priština, Kosovo \\ ${ }^{2}$ Klinika za Medicinsku Biohemiju, Sveučilišni Klinički Centar Kosova, Medicinski Fakultet-Univerzitet u \\ Prištini, Kosovo
}

Rad je primljen 11.4.2018. Rad je recenziran 18.4.2018. Rad je prihvaćen 29.4.2018.

\section{SAŽETAK}

Brojna istraživanja u posljednjih nekoliko desetljeća ukazuju na porast uporabe novih sintetičkih droga i tzv."ovisnosti bez droga" uz istovremeni pad uporabe opijata. Globalizacija i razvoj informacijske tehnologije su važni pokretači u ovom smjeru. Razumijevanje ukupnih trendova u korištenju novih sintetičkih droga složeno je zbog činjenice da one često jedna drugu zamjenjuju, budući da potrošači donose odluke prema njihovoj dostupnosti, cijeni i percipiranoj "kvaliteti". Modifikacijom molekula poznatih droga dobivaju se spojevi potentnijih farmakodinamskih svojstava. Proizvode se u formi praha, tableta, kapsula ili rastvora. Imaju stimulativno ili depresivno djelovanje, a konzumiraju se oralno, ušmrkavanjem praha, injekcijom i sl. Dizajnirane droge imaju i vrlo neugodne, čak potencijalno smrtne neželjene efekte. Nove sintetičke (dizajnirane) droge su naša stvarnost, a zanimanje društva za te tvari sve je veće. Posebnu pozornost liječnika privlači metamfetamin, jer korisnici tog pripravka sve češće dospijevaju na odjele intenzivne njege, što predstavlja veliko opterećenje za sustav zdravstvene zaštite. Iako su kaznene mjere za proizvodnju i distribuciju dizajniranih droga stroge, to ne sprječava njihovu daljnju proizvodnju i distribuciju.Stalni porast broja dizajniranih droga, kao i učinaka koje proizvode, doveo je do pojave novih obrazaca ponašanja u svezi s korištenjem tih tvari. Otkako je ecstasy pokrenuo raverevoluciju, ovisnici su u potrazi za novim "super drogama”.I pored brojnih štetnih učinaka na zdravlje ovisnika i negativnih posljedica na njegovu okolinu popularnost novih sintetičkih droga raste i u njihovom sprečavanju potreban je timski rad u sklopu integralnog $\mathrm{i}$ multidiscplinarnog pristupa liječenja te potpora cjelokupnog društva.

Ključne riječi: sintetičke, dizajnirane, droge

Osoba za razmjenu informacija:

Dr.Shpend Haxhibeqiri, Psihijatar

E mail: dr.shpendhaxhibeqiri@gmail.com

\section{UVOD}

Kroz cijelu povijest čovjeka prati vlastita neumjerenost u težnji za uživanjem. U pet tisuća godina zabilježene povijesti zapisano je kako su ljudi od postanka čovječanstva na razne dopuštene i nedopuštene načine nastojali sebi život učiniti ugodnijim i ljepšim. Pri tome su koristili razna sredstva i načine kojima su to povremeno i privremeno i uspijevali, ali su dugoročno uništavali svoje zdravlje uključujući pri tome organsku, psihičku i socijalnu stastavnicu pojedinačno ili sve tri skupa. Razlog tome je nastanak ovisnosti zbog kojega se užitak vrlo brzo pretvarao u patnju (1).Više istraživanja u posljednjih nekoliko desetljeća ukazuje na pad uporabe opijata, a na porast uporabe novih sitetičkih droga i tzv."ovisnosti bez droga"(2-4).

Termin sintetičke ili dizajnirane droge uveden je na prijedlog profesora Gary Hendersona sa Sveučilišta u Kaliforniji, koji je prvi predvidio opasnost od njihovog štetnog djelovanja i brzog širenja. Henderson je tim terminom označio droge koje se sintetiziraju iz postojećih tvari (prekursora), pri čemu se mijenja njihova kemijska struktura. Njihovi efekti 
oponašaju učinke prirodnih psihoaktivnih supstanci, ali su brojniji i jači uz istovremenu manju cijenu i veću i lakšu pristupačnost. Njihova distribucija nije podvrgnuta legalnoj kontroli (4). Langston i Rosner pod pojmom "dizajnirane droge" podrazumijevaju skupinu ilegalnih droga koje strukturno i po svojim efektima liče na kontrolirane psihoaktivne tvari, ali koje nisu službeno proglašene za ilegalne tvari (5). U stručnoj i znanstveno-popularnoj literaturi često se srećemo s izrazima dizajnirani hormoni, dizajnirani geni ili dizajnirani lijekovi. Njihova proizvodnja započinje 1856. kada je William H. Perkin, u želji da sintetizira kinin, slučajno dobio sasvim nepoznatu tvar. Bila je to prva sintetska anilinske boja koja je uskoro omogućila razvoj kemijske industrije diljem svijeta. To otkriće učinilo je Perkina vrlo bogatim čovjekom, a otkriće sintetičkih spojeva predstavljalo je pravu revoluciju u znanosti (6).

Proizvodnja sintetičkih droga vrši se s ciljem da se dobiju tvari koje imaju slična djelovanja i učinke kao prirodne psihoaktivne tvari. Njih sintetiziraju nedovoljno educirane osobe, tzv. kuhinjski kemičari, koji rade u ilegalnim laboratorijama. Rastvori tih supstanci nerijetko su biološki ili kemijski kontaminirani, pa se često dobiju nedovoljno čiste tvari loše kvalitete. Osim toga, dovoljno je da se neka od faza sinteze produži ili da se tvar tijekom prerade pregrije, pa da se dobije izuzetno opasan otrov. Neke od tvari koje se koriste $\mathrm{u}$ sintezi droga vrlo su zapaljive (npr. fosfin, etanol, benzen). Ima i onih koje u reakciji s vodom ili kisikom mogu eksplodirati (npr. spojevi magnezija, natrija i sl.). Oko trećine ilegalnih proizvođača droga policija otkrije nakon eksplozija u laboratorijima prilikom sinteze. Broj dizajniranih droga izuzetno je veliki. Najpoznatiji su analozi fentanila i meperidin (tzv. sintetički opioidi), fenciklidin, amfetamin i metamfetamin (ecstasy, speed, ice, cat) koji imaju halucinogena i stimulativna svojstva (7).

Sve veći broj ilegalnih laboratorija diljem svijeta nije samo problem zdravstva, već i šire društvene zajednice. Tijekom devedesetih godina prošlog stoljeća najviše ilegalnih laboratorija otkriveno je $\mathrm{u}$ Kaliforniji. S problemom zlouporabe dizajniranih droga sve više se suočavaju Kanada, Australija i zemlje istočne Europe. Među nove centre ilegalne proizvodnje dizajniranih droga spadaju Mađarska, Češka, Rusija. U tim sredinama najpopularniji su sintetski opioidi i psihotomimitski fenetil-amini (ecstasy i njegovi analozi). Interesantno je da su ilegalne laboratorije u Mađarskoj, Češkoj, Litvi i Estoniji i uglavnom specijalizirane za proizvodnju amfetamin dok se u Rusiji proizvode sintetski opioidi. U Republici Češkoj je tijekom 1994. otkriveno više od sedamdeset ilegalnih laboratorija u kojima se proizvodio amfetamin. Neke od njih bile su pod financijskom kontrolom nekih zemalja Zapadne Europe jer su i proizvodile MDMA za to tržište. Sličan slučaj zabilježen je i u Mađarskoj, gdje je te godine nađeno 50 kg MDMA (8).

Dizajnirane droge se mogu naći pod različitim nazivima koji ovise od proizvođača, mjesta, vremena i često se mijenjaju. Obično ih na tržištu nalazimo pod vrlo neobičnim, "misterioznim" nazivima poput Ecstasy, China White, X, Persian White, Mexican Brown, Adam and Eve, XTC, Dust, MPTP, MDMA, Tango and Cash, Crystal i Polo. Odabir takvih naziva ima za cilj da privuče pažnju potencijalnih konzumenata mlađeg uzrasta. Dizajnirane droge se ne proizvode $u$ medicinske svrhe. Učinci tih tvari su ciljani i jasno definirani. Modifikacijom molekula poznatih droga dobivaju se spojevi potentnijih farmakodinamskih svojstava. Proizvode se $\mathrm{u}$ formi praha, tableta, kapsula ili rastvora. Imaju stimulativno ili depresivno djelovanje, a konzumiraju se oralno, ušmrkavanjem praha, injekcijom i si. Dizajnirane droge imaju i vrlo neugodne, čak potencijalno smrtne neželjene efekte. Najčešće fizičke manifestacije su pospanost, tremor, poremećaj govora, zamagljenje vida, vrtoglavica i trajno oštećenje središnjeg živčanog sustava. U psihološke manifestacije spadaju euforija, konfuzija, razdražljivost, anksioznost, ekstremna emocionalna senzitivnost, halucinacije, depresija, sumanuti sadržaji, sklonost agresivnim atacima i dr. (9).

Neke od dizajniranih droga služe kao "estetski pojačivači”, pospješujući vizualnu ili auditivnu percepciju pred polazak na koncert, kazališnu predstavu ili izložbu slika. U te svrhe obično se koristi feniletilamin (2CB ili DOM) u malim dozama. $\mathrm{Za}$ 
rave zabave "preporučuju” se dizajnirane droge koje primarno dovode do euforije, povećavaju komunikativnost i empatski potencijal. Iz tog razloga "najpopularnije" su ecstasy (MDMA) i njegovi derivati; za stimulaciju spolnog zadovoljstva i seksualne želje uzimaju se 2CB, 2CI, dok gama-hidroksibutirat (GHB) dovodi do inhibicije ponašanja. Sve je češća primjena dizajniranih droga i tijekom meditativnih aktivnosti (npr. u Zen budizmu), naročito MDA, MDMA, i to u malim dozama. Kombinirana uporaba više tvari postaje trend s povećanom prevalencom među mladima. Uglavnom se počinje s kombiniranjem alkohola i marihuane. Kada se razina tolerancije poveća, počinje ozbiljnije eksperimentiranje, čime se pojačavaju određeni efekti. Prema podatcima jedne šestomjesečne studije rađene u Velikoj Britaniji 33.093 ispitanika od ukupno 62.790, ili 64 $\%$, koristilo je više droga istovremeno i to $28 \%$ dvije droge, $15 \%$ tri, $7 \%$ četiri i $4 \%$ pet droga. Od lijekova se najčešće koriste benzodiazepini. Osobe koje konzumiraju sintetske droge znaju točan vremenski redoslijed uzimanja pojedinih tvari, čime produžavaju učinke tih, obično kratkodjelujućih tvari (10).

Dizajnirane droge su naša stvarnost, a zanimanje društva za te tvari sve je veće. Posebnu pozornost liječnika privlači metamfetamin (poznatiji kao Ice, Speed), jer korisnici tog pripravka sve češće dospijevaju na odjele intenzivne njege, što predstavlja veliko opterećenje za sustav zdravstvene zaštite. Iako su kaznene mjere za proizvodnju i distribuciju dizajniranih droga stroge, to ne sprječava njihovu daljnju proizvodnju i distribuciju.Stalni porast broja dizajniranih droga, kao i učinaka koje proizvode, doveo je do pojave novih obrazaca ponašanja u svezi $s$ korištenjem tih tvari. Otkako je ecstasy pokrenuo raverevoluciju, ovisnici su u potrazi za novim "super drogama”. Neke od dizajniranih droga služe kao "estetski pojačivači", pospješujući vizualnu ili auditivnu percepciju pred polazak na koncert, kazališnu predstavu ili izložbu slika (11).

\section{KLASIFIKACIJA SINTETIČKIH DROGA}

Sintetičke droge mogu se klasificirati prema kemijskoj strukturi ili prema predominantnom farmakološkom učinku. Kemijska klasifikacija je prilično jednostavna, dok je farmakodimska podjela tih tvari složena, prvenstveno zbog mnogobrojnih učinaka tih droga. $U$ tablici 1 . navedeni su najčešći predstavnici svih kategorija sintetičkih droga. I pored toga što je službeno uveden u znanstvene krugove 1985, termin "dizajnirane droge" nije našao svoje mjesto u okviru suvremenih klasifikacijskih sustava. U desetoj reviziji Međunarodne klasifikacije bolesti (MKB-10), u bloku Mentalni poremećaji i poremećaji ponašanja zbog uporabe psihoaktivnih tvari (F10-F19), ne postoji odvojena kategorija za postavljanje dijagnoze dizajniranih droga $(12,13)$. Jedino je moguće da, na temelju gore navedene podjele, utvrdimo skupinu kojoj sintetička droga pripada i da je u skladu s tim uvrstimo u neku od postojećih kategorija (opioidi, kanabinoidi, stimulansi, halucinogeni i sl.) (6).

Klasifikacija sintetičkih droga:

1. Psihotomimetski feniletilamini: MDMA (Ecstasy, Adam, XTC), derivati MDMA, supstituti MDMA.

2. Stimulansi CNS-a: norefedron (CAT), efedron, $\mathrm{N}$-dimetilamfetamin (Speed).

3. Sintetička opioidi: analozi meperidina, analozi fentanila.

4. LSD analozi: morfolinski derivat (LSM), etilpropilamid.

5. Psihotomimetski indolalkilamini: DPT, DIPT, DAT; psilocin, psilocibin.

6. Sintetički kanabinoidi: $\mathrm{D}^{3} \mathrm{THC}, \mathrm{D}^{9} \mathrm{THC}$ ("superhash"), D ${ }^{8}$ THC.

7. Fenciklidin (PCP) i analozi: cikloheksanonski derivat-Ketamin/Ketalar (Green, Purple, K, Special K), fenciklidin (Angel dust, Hog, PCR Cadillac, Crystal).

8. GHH - gamahidroksibutirat:(Tekući Ecstasy, G), Liquid.

9. Motakvalon i njegovi analozi: (Sopors, Heroin for Lovers, Lude).

10. Deliranti:1 metil-3-piperidil benzilat (JB-336), fenil glikolat). 


\section{PSIHOTOMIMETSKI FENILETILAMINI}

Psihotomimetske droge karakterizira njihova sposobnost da u čovjeka mijenjaju raspoloženje, tijek misli i percepciju. Kod zdravih osoba mogu poremetiti psihičku ravnotežu i izazvati prolazne psihoze. Ova klasa tvari poznata je pod različitim nazivima - psihodelici, halucinogeni, psihodisleptici, psihotogeni, psiholitici, fantastika, ali ni jedan od njih nije sasvim odgovarajući pa se najčešće koristi generički naziv psihotomimetici. Većina psihotomimetskih feniletilamin sintetizirana je 60-ih godina. Do sada je testirano više od stotinu spojeva te grupe, pri čemu je za većinu potvrđeno da su biološki aktivni. Riječ je o drogama čija je sinteza iznimno jednostavna, zbog čega su vrlo popularne među ilegalnim proizvođačima. Značaj ovih droga je utoliko veći što one same izazivaju psihoze, a djeluju sinergistički ili antagonistički s drugim tvarima, što znači da potenciraju ili inhibiraju učinak tih droga (4).Sintetički feniletilamini se, prema farmakološkom djelovanju koje proizvode, mogu podijeliti u dvije podskupine. U prvu spadaju fenetilamini koji izazivaju euforiju i stimuliraju komunikativnost. U drugu podskupinu spadaju feniletilamini koji dovode do obilja halucinatornih doživljaja, iluzija, izmjena u percepciji tjelesne sheme, boje, zvukova, prostora i vremena. Osim toga, te droge mogu dovesti do pojave depersonalizacije, euforije, emocionalne labilnosti, anksioznosti, intenzivnog straha, neprijateljskog stava i poremećaja rasuđivanja, te su vrlo slične klasičnim halucinogenima (14). Prema farmakološkom djelovanju, ovu skupinu droga možemo podijeliti na: MDMA i njegove derivate, supstitute MDMA i povremene supstitute MDMA i na grupu ostalih feniletilamina.

\section{Ecstasy (MDMA) i njegovi derivati}

Prva sintetizirana droga iz ove klase je 3,4-metilendioksiamfe-tamin (MDA), poznata pod uličnim imenima Love drug ili Zen. Bila je vrlo popularna krajem šezdesetih godina $(15,16)$. Ova droga, zajedno sa 3,4-metilendioksi-N-propilamfetamin (MDPR), tzv. Prajmer), spada u N-propil derivate, mada njihovo djelovanje ne nalikuje u potpunosti djelovanju Ecstasija. Modifikacijom kemijske strukture MDA dobiveni su još: 3,4-metilendioksimetamfetamin (MDMA), poznatiji kao Ecstasv, ADAM ili XTC; N-etil -3,4-metilendi-oksiamfetamin (MDEA), poznat pod uličnim imenom EVE; i $\mathrm{N}$-hidroksi -3,4-metilendioksiamfetamin (MDOH); kao i MDAOH (17).

Ecstasy ili MDMA (3,4-metilendioksimetamfetamin) ima kombinirano stimulativno i halucinogeno djelovanje, te ga zovu i halucinogeni stimulans. Od 1960. se primjenjuje u nemedicinske svrhe. Sve do sredine osamdesetih MDMA su koristili psihijatri i psiholozi u liječenju osoba sa specifičnim psihološkim smetnjama, npr. u liječenju depresije. Danas MDMA obično konzumiraju tinejdžeri, osobito ljubitelji noćnih klubova, tehno glazbe i rave zabava. Ulična imena tog preparata su Adam, AL, XTC, Claritv, A Bean, Baby slits, Chocolate chips, Euphoria, Essence, Stacy, Lover 's Speed, Eve. Obično se nalazi $\mathrm{u}$ formi tablete, kapsule ili praha, a uzima se oralnim putom, rjeđe injekcijom. Neki ga kombiniraju s metadonom, LSD-em ili sintetičkim opoidima. Sadržaj tableta koje se kupuju na ulici je nepouzdan; obično sadrže druge psihoaktivne supstance kao što su kofein, efedrin, amfetamin i sl. Zbog toga se proizvode testeri za MDMA, kojima je moguće provjeriti sadržaj tablete(5).

MDMA dovodi do povećanog oslobađanja serotonina u sinapsu i inhibicije njegovog ponovnog preuzimanja. MDA i amfetamini imaju slična farmakodinamsko svojstva, pri čemu su MDMA i MDA pet puta jači inhibitori od amfetamina, a dvadeset puta jače od DOM-a (halucinogen). Iz tog razloga MDA i MDMA nisu klasični halucinogeni. Na temelju navedenih podataka, pretpostavlja se da su stimulativna djelovanja MDMA uzrokovana modifikacijom dopaminske i noradrenalinski neurotransmisije, dok je izmjena u serotoninski sustavu odgovorna za halucinogene efekte tog pripravka (18).

U umjerenim dozama MDMA dovodi do euforije, pospješuje mentalno i emocionalno funkcioniranje, ali može dovesti do ataka anksioznosti ili paranoje (19-22). Djelovanje tvari traje od 6 do 30 sati. Veće doze izazivaju halucinatorne doživljavanja, specifične senzacije, depresiju, generiraju sumanute ideje i nasilno, iracionalno ponašanje. Droga 
maskira osjećaj umora i žeđi, a višesatno plesanje u zagušljivim i prepunim klubovima može uzrokuje pregrijavanja tijela, gubitak tekućine, i time izazvati smrt. Toplinski udar, u blažoj formi, uzrokuje kočenje mišića vilice i drugih mišića u tijelu (zbog nedostatka soli i gubitka tekućine), aritmije srca i povišeni krvni tlak. Zbog toga mogu otkazati i bubrezi, jetra, a u nekim slučajevima dolazi i do edema mozga zbog unosa prevelike količine tekućine. Osoba u takvom stanju ima glavobolju, povraća i pospana je, što također može uzrokovati moždani udar i smrtni ishod. Dugoročni učinci i rizici su slabo poznati. Zbog oštećenja živčanih stanica, može doći do mentalnih oboljenja $(20,23,24)$. Postoji mogućnost da se razvije depresija čak nekoliko godina nakon prestanka uzimanja droge. Što se tiče kontraindikacija, treba reći da ecstasy stupa u interakcije s različitim drogama. Ukoliko se uzima s inhibitorima monoaminoksidaze, koji se često propisuju kao antidepresivi, može doći do opasno povišenog krvnog tlaka, što također može rezultirati smrću. Na temelju dosadašnjih studija, liječenje adverzivnih psihotičinih epizoda uključuje primjenu antipsihotika uz obvezan hospitalni tretman (25).

Ostali fizički efekti tog preparata su gubitak apetita, mučnina, povraćanje, pomućenje vida i tremor. Moguća je pojava nesanice, grčeva i nevoljnih pokreta. Neki od tih efekta perzistiraju i do dva tjedna od uzimanja posljednje doze preparata. Tim nuspojavama posebno su sklone trudnice, osobe sa srčanim smetnjama, epilepsijom ili povišenim krvnim tlakom. Istraživanja na animalnom modelu pokazuju da ecstasy razara serotoninske neurone, dovodeći do dugotrajnog smanjenja razine serotonina $u$ SŽS-u. Riječ je o moždanim strukturama koje reguliraju i kontroliraju agresivnost, raspoloženje, seksualnu aktivnost, spavanje, osjetljivost, bol. Osim toga, dokazano je da ecstasy reducira otpornost na infekcije, naročito urinarnog i respiratornog sustava (3).

\section{Supstituti MDMA}

Supstance svrstane u ovu skupinu proizvode fizičke efekte slične ecstasy (kardiovaskularne poremećaje, povišenu tjelesnu temperaturu, dehidraciju), ali su slabijeg intenziteta. Nalazimo ih pod različitim nazivima: MDBA (J; BDB), MDBB (Eden; MBDB; MJ; Metil-J), ALPHA; MALPHA, N-hidroksi derivat MDMA, MEPEA, 4EMA; TMA i dr. Supstituti MDMA vrlo su česti na ilegalnom tržištu, potentni su stimulatori komunikacije ali ne proizvode izražene anoreksične efekte poput MDA i njegovih derivata. Ovo navodi na zaključak da je stimuliranje komunikacije u vezi s derivatom 1,3-benzo-dioksola. Ostale tvari iz ove skupine izazivaju euforiju i manje-više stimuliraju komunikativnost, te se često konzumiraju na rave zabavama (6).

\section{STIMULANSI SREDIŠNJEG ŽIVČANOG SUSTAVA}

Kinezi su još prije 5000 godina koristili biljku Mahung, a Nagai je (1887. g.) otkrio da je glavni aktivni sastojak Ma-hunga efedrin, a te iste godine je Edeleau prvi sintetizirao analog efedrina - amfetamin. Amfetamin je 1932. uveden kao supresor apetita, ali je zbog velikog adiktivnog potencijala prepisivan samo u liječenju narkolepsije i poremećaja deficita pažnje s hiperaktivnošću i drugih hiperkinetskih stanja. Psihoaktivne supstance iz ove kategorije rijetko izazivaju samo stimulativne učinke, već dovode do euforije, povećavaju psihomotoriku i poboljšavaju raspoloženje. Pri većim dozama dolazi do nemira, razdražljivosti, konfuzije, pojačanih refleksa, povišenog krvnog tlaka i srčanožilnih smetnji (13).

\section{Amfetamin}

Amfetamin je opći naziv za klasu stimulansa u koje spadaju amfetamin, metamfetamin, dekstroamfetamin i dr. Ove tri supstance imaju vrlo slične kemijske strukture i proizvode slične učinke. Ovdje spada i metkatinon, koji je kombinacija amfetamina i katinona. Ove tvari imaju različite nazive u slengu kao što su: speed ( $\mathrm{N}, \mathrm{N}$-dimetil-amfetamin), norefedron (CAT), efedron (Jeff, CAT), ice (4,5-di-hidro-4-metil-5- fenil-2-oksazolamin), metamfetamin hidroklorid u obliku čistih prozirnih komadića sličnih ledu, koji se puše. Ostala imena su Glass, Crank, Go-fast, shabo-shabo, Fire, Go, Zip, Meth, Cristy i Chalk, Shabu.Amfetamin je čvrst SŽS stimulans, a djeluje centralno i periferno. Vrlo brzo prolazi krvno-moždanu barijeru procesom aktivnog 
transporta, uglavnom se izlučuje preko urina, ali i znojem u sličnoj koncentraciji. Kompleksni mehanizmi djelovanja amfetamina na ponašanje $u$ vezi su s njegovim blokiranjem mehanizama ponovnog preuzimanja katekolamina. Dominiraju euforični efekti, produžena budnost, gubitak apetita. Amfetamin izaziva hiperaktivnost, nemir, tremor, agitaciju, nesanicu, povišeni krvni tlak, nepravilnu srčanu akciju (3).

Metamfetamini pripadaju velikoj obitelji amfetamina. To je vrlo adiktivni stimulans koji aktivira određene moždane stanice, podižući raspoloženje i tjelesnu pokretljivost. Metamfetamin je kemijski srodan amfetaminu, ali su njegovi učinci na SŽS jači i brži. Koristi se u medicinske svrhe, najviše u liječenju gojaznosti, narkolepsije i poremećaja deficita pažnje s hiperaktivnošću (ADHD), ali je njegova terapijska uporaba ograničena. Metamfetamin je stimulans II kategorije, što znači da ima visok adiktivni potencijal za zlouporabu i dostupan je jedino preko recepta. Početkom sedamdesetih evidentna je prava epidemija zlouporabe i ilegalne proizvodnje te tvari, usporedo sa smanjenjem legalne proizvodnje. Legalna forma metamfetamina može se nađe na tržištu pod zaštićenim nazivom Desoxyn ${ }^{\circledR}$, a najčešće se prepisuje u cilju liječenja pretilosti.Nedavne studije bilježe da je tijekom 1996. 4,4\% učenika srednjih škola bar jedanput tijekom života konzumiralo metamfetamin. Konzumacija metamfetamina sve je češća kod muškaraca kao i u žena. Obično ga zloupotrebljavaju mladi raveri i ljubitelji noćnih klubova, kao i osobe čiji poslovi zahtijevaju koncentraciju, budnost i fizičku koordinaciju tijekom duljeg vremenskog razdoblja.Koristi se oralno, intranazalno, ubrizgavanjem u venu ili se puši, a brzina kojom se efekti javljaju ovisi od načina uzimanja. Neposredno nakon inhalacije ili intravenske injekcije javljaju se intenzivne tjelesne senzacije, tzv. rush ili flash, koje traju svega nekoliko minuta, a praćene su doživljajem zadovoljstva. Ukoliko se puši ili se uzima u parenteralnoj formi, efekti se javljaju već poslije 5-10 sekundi. Ušmrkavanje ili oralna administracija dovode do euforije, ali ona nije intenzivna. Ukoliko se ušmrkava, efekti se javljaju nakon 3-5 minuta a nakon oralne ingestije djelovanje se javlja 15-20 minuta. Efekti metamfetamina na SŽS znatno su blaži ukoliko se preparat puši, a u usporedbi s drugim drogama, npr. s kokainom, efekti speeda su dugotrajniji (13).

Metamfetamin oslobađa velike količine neurotransmitera dopamina koji stimulira moždane stanice, podižući raspoloženje i tjelesnu pokretljivost. Nakon određenog vremena metamfetamin uzrokuje smanjenje razine dopamina, što može dovesti do simptoma sličnih onima kod Parkinsonove bolesti. Istraživanja na životinjama pokazuju da velike doze metamfetamina oštećuju neuronske završetke. Prema podacima američkog Nacionalnog instituta za zlouporabu droga (National Institute on Drug Abuse - NIDA), metamfetamin mnogo brže prolazi krvno-moždanu barijeru u odnosu na druge članove amfetaminske obitelji jer se bolje rastvara u staničnim membranama neurona, tako da vrlo brzo dovodi do euforije, naročito kada se uzima parenteralnim putom ili kada se puši. Djelovanje na SŽS javlja se već pri uzimanju niskih doza metamfetamina, uključujući povećanu budnost, pojačanu fizičku aktivnost, redukciju apetita, ubrzano disanje, povišenu tjelesnu temperaturu i euforiju. Čak i male doze speeda mogu dovedu do ekscitacije. Ostali učinci na SŽS su nevoljni pokreti, razdražljivost, nesanica, konfuzija, tremor, anksioznost, agresija, povišena tjelesna temperatura i grčevi. Zadnja dva efekta mogu uzrokovati smrt (3).

Tolerancija na matamfetamin se javlja izuzetno brzo. Ugodni efekti nestaju prije nego što koncentracija droge u krvi znatno opadne, pa ponovnim uzimanjem konzumenti nastoje produže djelovanje. U početku je vremenski razmak između uzimanja doza oko šest sati, a vremenom se skraćuje na tri odnosno dva sata. Obustava konzumiranja metafetamina predstavlja izuzetno težak i bolan proces.Najčešći znaci intoksikacije su uznemirenost, smanjeni apetit, govorljivost, povećana fizička aktivnost, suha usta, proširene zjenica, mučnina, povraćanje. Česte su epizode agresivnog ponašanja, paranoidni sadržaji, vizualne i slušne halucinacije, nesanica, poremećaj pamćenja, kao i kompulzivno ponašanje, naročito čišćenje, pomicanje predmeta i sl. što može rezultirati pokušajem ubojstva i samoubojstva. Javljaju se 
kardiovaskularne smetnje u vidu intenzivnog boli u prsima, povišenog krvnog tlaka, ubrzanog rada srca, mogućeg kardiovaskularnog kolapsa, kao i smrti. U preostale neželjene učinke metamfetamina spadaju iregularna srčana akcija, srčani infarkt, poremećaj funkcije disanja, smanjenje imunosti, odgovora i ekstremna anoreksija.U slučaju da se metamfetamin zlouporabljuje duže vremena, moguća je pojava kliničke slike nalik na shizofreniju koju karakterizira obilje sumanutih sadržaja, halucinatorne doživljavanja, stereotipije i formikacije. Iako ne postoje karakteristični fizički simptomi tijekom obustave metamfetamina, konzumenti obično navode povećanu želju za konzumacijom tvari, depresivno raspoloženje, gubitak apetita i pojačan apetit (3).

\section{$\mathrm{N}$-dimetilamfetamin (Speed)}

Speed je stimulans SŽS-a koji se vrlo često zlouporabljuje. Obično se ušmrkava, puši ili uzima injekcijom, a uobičajena doza se kreće u rasponu od 25 do $40 \mathrm{mg}$. Duljina trajanja djelovanja tvari nije poznata, a ovisi o uzete doze, načina uzimanja, čistoće tvari i dr. Uzimanje injekcijom je najopasnije jer amfetamin gotovo istovremeno dolazi do SŽS-a, što povećava mogućnost za predoziranje. Može doći i do raznih infekcije - hepatitisa $\mathrm{C}$, sepse, uništavaju se vene, javljaju se tromboza i apsces. Speed smanjuje apetit i želju za spavanjem, a dugotrajna uporaba može rezultirati ozbiljnim mentalnim i psihičkim smetnjama. U toksične manifestacije spadaju hiperaktivnost, konfuzija, povišeni krvni tlak, srčanožilni poremećaji, povišena tjelesna temperatura, grčevi (6).

\section{4,5-dihidro-4-metil-5-fenil-2- oksazolamin (ICE)}

Najčešći ulični nazivi su ICE, Blue ice, Euphoria i 4-MAX. Prema tipu akcije spada u stimulanse, euforizante i anorektike. Doza se kreće u rasponu od 15 do $25 \mathrm{mg}$, administrira se oralno, pušenjem ili se ušmrkava, a učinak traje jako dugo. $U$ toksične manifestacije spadaju hiperaktivnost, konfuzija, povišeni krvni tlak, srčanožilne bolesti, povišena tjelesna temperatura, grčevi, toksična psihoza. Ova tvar se naročito konzumira u Sjedinjenim američkim državama i Europi, uglavnom na rejv zabavama zbog svojih stimulativno-euforizantnih svojstava $(6,26)$.

\section{Metcatinon, norefedron (CAT)}

Metkatinon predstavlja kombinaciju metamfetamina i katinona. Poznat je pod uličnim nazivom CAT, au posljednjem desetljeću XX stoljeća bio je vrlo popularna droga u Sjedinjenim američkim državama. Učestalost njegove zloupotrebe je ograničena. Prosječna doza za postizanje željenog efekta iznosi 10 do $15 \mathrm{mg}$, a učinak traje tri do četiri sata. Riječ je o supstanci koja energizira, poboljšava raspoloženje, smanjuje apetit, poboljšava komunikaciju. Psihičke manifestacije u akutno intoksiciranih osoba su u vidu gubitka apetita, mršavljenja, depresije i slabosti, pri čemu osoba manifestira nasilno ponašanje. $U$ najčešće toksične manifestacije spadaju hiperaktivnost, euforija, konfuzija, pričljivost, nekontrolirano smijanje, nesanica, kardiovaskularni poremećaji, povišena tjelesna temperatura, grčevi. Kronična zlouporaba oštećuje zube i desni, javlja se impotencija, iregularna srčana akcija, pa i smrtni ishod. Nova sintetizirana droga iz ove klase poznata je kao CRYSTAL. Izgleda kao kristalni šećer ili gorski kristal, po čemu je i dobila ime. Ovaj metamfetaminski derivat jači je od ecstasy-a, konzumira se ušmrkavanjem ili pušenjem i uzrokuje agresivna stanja. Opijenost traje između 12 i 70 sati, a ovisnost se javlja već poslije prvog konzumiranja. Droga potječe iz Sjeverne Amerike i Meksika, a vrlo je popularna u Njemačkoj i Češkoj (14).

\section{SINTETIČKI OPIOIDI}

Postoji oko četiri tisuće analoga sintetizirano u cilju pronalaženja idealno potentnog analgetika koji ne bi stvarao ovisnost. Najčešće psihičke manifestacije ovih tvari su euforija, smirenost, neosjetljivost na bol, redukcija anksioznosti. Osim toga, moguća je pojava fizičkih manifestacija u vidu suženja zjenica, mučnine i povraćanja, depresije disanja, ortostatske hipotenzije, poremećaja motiliteta probavnih organa i grčeva, kao i plućnog edema, koji je najčešća smrtna komplikacija koja se javlja pri predoziranju. Kronična zlouporaba opioida dovodi do razvoja tolerancije, psihičke i fizičke ovisnosti. 
Sintetički opioidi se dijele u dvije skupine: analoge meperidin i analoge fentanila. Meperidin, poznat pod zaštićenim nazivom Demerol ${ }^{\circledR}$, sintetiziran je 1947. godine u Kaliforniji (14).

\section{Analozi meperidina}

Meperidin je poznatiji pod zaštićenim nazivom Demerol$^{\circledR}$. Tijekom 90 -ih godina XX stoljeća ilegalna proizvodnja i distribucija tog preparata značajno je porasla. Među analoge meperidin, koji su se pojavili na ilegalnom tržištu, nalaze se l-metil-4-fenf II propionoksipiperidin (MPPPJ) i l- [2-feniletil] -4-acetiloksipiper din (PEPAP). Obično se nabavlja pod uličnim nazivom „novi heroin“. MPPP (sintetički heroin, novi heroin) čvrst analgetik koji je sintetiziran još 1947., ali nikada nije ušao u kliničku praksu. MPPP je popularan među narkomanima jer pri parenteralnoj administraciji izaziva euforiju slično heroinu (3).Sinteza MPPP je vrlo teška i složena. Temperatura tijekom njegovog dobivanja mora konstantno iznositi $19^{\circ} \mathrm{C}$, u trajanju od deset sati. Ukoliko temperatura poraste, umjesto MPPP sintetizira se veoma jak otrov, l-metil-4-fenil-1, 2,3,6,-tetrahidro-pi-ridin (MPTP), koji je snažan neurotoksin i izaziva trajno oštećenje dopaminergičkih neurona. Klinička manifestacija strukturalnog oštećenja središnjih struktura su znaci parkinsonizma (povećanje mišićnog tonusa, teškoće u govoru i pokretima, ukočenost ekstremiteta). Međutim, u ovom slučaju tremor se predominantno javlja na proksimalnoj muskulaturi, dok se kod idiopatskog parkinsonizma obično javlja tremor u miru. MPTP je prvobitno registriran u Kaliforniji ranih osamdesetih. Oksidacijom tog pripravka nastaje metilfenildihidropiridin (MPP+) koji se selektivno vezuje za mitohondrije u dopaminergički stanicama substantia nigra, što ima za posljedicu razaranje pokretnih struktura te regije (14).

\section{Analozi fentanila}

Ranih osamdesetih u ilegalnim laboratorijima započela je proizvodnja analoga fentanila, prvenstveno zbog farmakološke sličnosti s heroinom i morfinom. Postoji oko 1400 potentnih analoga koji imaju 80 do 1000 puta jače djelovanje od heroina, odnosno 200 do 1000 puta su potentniji od morfina, a neki su i slabiji. Te droge imaju brz početak akcije (1 do 4 minute od konzumiranja) i kratkotrajno djelovanje (od 30 do 90 minuta). Međutim, ponekad i male doze analoga fentanila mogu dovesti do iznenadnog smrtnog ishoda, obično uslijed depresije disanja. U slučaju predoziranja daje se nalokson koji suzbija depresiju disanja. Nedavno objavljene studije ukazuju na to da su pušenje i ušmrkavanje svih popularniji načini konzumiranja vjerojatno i zato što konzumenti pokušavaju izbjeći prenošenje HIV/ AIDS.Najpoznatiji analog fentanila je ct-metifentanil ili AMF, poznatiji pod imenom „China White“ ili Novi heroin, a-metifentanil se na ilegalnom tržištu pojavio 1979. Četiri godine kasnije sintetiziran je i 4-fluorofentanil, u slengu poznat kao China White, Tango \& Cash, GoodFella, Mexican brown, China town, Poison, Synthetic ili Friend.Učestalost zlouporabe je ograničena, a prema tipu akcije spada u euforizante i analgetike. Doza se kreće od 0,05 do $0,125 \mathrm{mg}$, učinak traje kratko, a znaci intoksikacije javljaju se u vidu suženja zjenica, povraćanja, ortostatske hipotenzije, zatvora, grčeva, mišićne hiperaktivnosti, depresije disanja (10).

Droga je prvi put registrirana 1979. u Kaliforniji. To je prvi sintetski analog fentanila koji je uzrokovao brojne smrtne slučajeve uslijed predoziranja. Izuzetnu „popularnost“ ta droga je stekla prije svega zbog učinaka sličnih onima koje izaziva heroin, pri čemu je od njega potentniji oko tisuću puta. Sintetizira se u mnogobrojnim ilegalnim laboratorijima, prvenstveno u SAD-u, u formi bijelog praha, konzumira se najčešće parenteralno i nazalno. Izuzetno je adiktivna tvar i gotovo svatko tko je proba pokazuje tendenciju da je konzumira ponovo. Kontinuirano uzimanje te droge dovodi do bolnih opstipacija pa se često uzima zajedno s laksativima. U ostale nuspojave spadaju bolovi i ukočenost mišića, nizak krvni tlak, nekontrolirani pokreti ekstremiteta i glave, depresija disanja, paraliza i sl. Pošto je preparat obično loše kvalitete, česta su predoziranja (3).

\section{ANALOZI LSD}

Jedan od glavnih i najpoznatijih predstavnika halucinogenih narkotika je dietilamid lizergične 
kiseline (LSD). Dobiva se ekstrakcijom iz jedne vrste gljiva koja uspijeva na raži. Naziv LSD potječe od njemačkog naziva Lysergic Saure Diaethyllamid. Primamljiv je za uličnu prodaju zbog visoke potentnosti i relativno lake proizvodnje. To je jedna od najpotentnijih tvari kojom se mijenja raspoloženje. $\mathrm{U}$ čistom stanju on predstavlja prašak bez boje, mirisa i okusa. Uzima se oralno, najčešće se liže s komadića upijajućeg papira ili drugih predmeta koji su njim impregnirani, s kockom šećera ili na tabletama u kojima se nalazi tekuća droga. Rijetko se uzima injekcijom, a tada efekte pokazuje već nakon dvadeset minuta, pri čemu učinak može trajati od nekoliko sati do čak nekoliko dana. LSD se na uličnom tržištu prodaje u obliku tableta, kapsula, samo povremeno kao tekućina bez boje, blago gorkog okusa. U svijetu ovisnika najčešći mu je naziv trip, ali je kod nas poznat pod imenima biserna kapija, rajska glazba, kiselina, svadbena zvona, jastreb, nebo, šećer, plava kiselina, zen (3).

Nekoliko analoga LSD-a sporadično se detektira $\mathrm{u}$ prodaji unatoč njihovoj generalno niskoj potentnosti, Etilpropilamid pokazuje oko $50 \%$ psihotomimetičke aktivnosti LSD-a kod čovjeka. Morfolid i metilpropilamid su još manji aktivni (oko $30 \%$, odnosno 10-15 \%). Mnogi drugi analozi LSD-a imaju vrlo slabo ili nikakvodjejstvo na čovjeka. Samo dva analoga su se pokazala potentniji od samog LSD-a, ali nema dokaza o njihovoj eventualnoj zlouporabi ili ilegalnoj proizvodnji. Prema izvorima koje je dala DEA, LSD uzorci uzeti iz ilegalnih izvora su u dozama od 20 do 80 mikrograma po dozi koja je značajno manja u odnosu na istraživanja 60 -ih i ranih 70-ih godina kada su se doze kretale u rasponu od 100-200 mikrograma ili više (6).

Droga stvara potpuno abnormalno opažanje zvučnih i vizualnih senzacija, te psihičke efekte gdje se javljaju brze promjene raspoloženja, u rasponu od jakog straha do euforije. Manifestiraju se suprotne emocije $\mathrm{u}$ isto vrijeme: sreća i tuga, depresija i dobro raspoloženje, napetost i opuštenost. Zbog iskrivljenog doživljavanja prostornih odnosa i osjećaja, osobe imaju dojam da se sve mogu. Zbog pogrešnih predstava o veličini predmeta, rastojanju, brzini i dubini, događa se da narkomani pokušavaju zaustaviti vlak u punoj brzini ili da skoče sa zgrade na zgradu. Gubi se osjećaj za granice vlastitog tijela i ličnosti u odnosu na vanjski svijet. Važno je napomenuti da osoba pod djelovanjem LSD-a može povrijediti i druge i sebe (10).

Fizičke manifestacije pri konzumiranju LSD-a su nepredvidljive i ovise od unesene količine, osobnosti konzumenta, raspoloženja i očekivanja, kao i od okruženja u kome je tvar uzeta. Obično konzument prve efekte osjeti 30 do 90 minuta nakon konzumiranja, a traju i do 12 sati. Fizički učinci uključuju povišenu tjelesnu temperaturu, ubrzan rad srca i povišeni krvni tlak, otežan govor, naježen kožu, mučninu, znojenje, gubitak apetita, nesanicu, suha usta, povećani mišićni tonus i tremor. Senzacije i osjećaje mijenjaju se mnogo dramatičnije od fizičkih znakova. Konzument može istovremeno osjeti nekoliko različitih emocija ili da brzo prelazi iz jednog emotivnog stanja u drugo. Ako uzeta veća doza, droga proizvodi halucinacije, tj. nastaju osjetilne promjene. Jasnije se osjeća dodir, okus i miris. Mijenja se i osjećaj za vrijeme kao i doživljavanje samog sebe. Događa se da osoba ima osjećaj da čuje boje ili vidi zvukove, da se pomiču zidovi, da osjeća strah od gubitka kontrole, od ludila ili smrti, kao i napade panike. Konzumenti ove efekte nazivaju tripovima, a negativne senzacije lošim tripovima. Česti su i fleshbeckovi koji mogu da se jave se od nekoliko dana do više od godinu dana nakon konzumacije LSD-a, a javljaju se iznenada, bez upozorenja, iako nije uzeta droga. Uglavnom ih doživljavaju osobe koje su kronično zloupotrebljavale halucinogene ili imaju naglašen poremećaj ličnosti. Rizik od konzumiranja LSD-a je pojava dugotrajne psihoze, npr. shizofrenije ili teške depresije. Sintezom novih droga, prije svega psihodeličnih, počelo se smatrati da one mogu imati i pozitivne učinke, naročito na stvaralaštvo. Uz pomoć njihovog djelovanja osoba produbljuje doživljavanje svoje ličnosti i vanjskog svijeta, aktivirajući nepristupačne regije psihe koji u normalnim uvjetima ostaju skriveni u području nesvjesnog. Oblici i boje se doživljavaju na novi način. To specifično iskustvo naziva se "psihodelično iskustvo", a umjetnost koja se pri tom, stvara "LSD" umjetnost" (3). 


\section{SINTETIČKI KANABINOIDI}

Kanabinoidi obuhvaćaju kanabinole, njihove karboksilne kiseline i metabolite. Nisu interesantni za ilegalnu proizvodnju zato što je na tržištu u velikim količinama dostupan prirodni tetra-hidrokanabinol (THC). Sporadično se jedino proizvodi A3THC, jer je lak za sintezu, kao i tetrahidrokanabinol-9-karboksilne kiseline (A9THC), rijetko A8THC. Ekstrakcija industrijske konoplje ili marihuane loše kvalitete dovodi do parcijalne sinteze THC izomera. Pri tom se dobiva smola s visokom koncentracijom inaktivnog kanabidola i THC-COOH, koji se potom ciklizacija i dekarboksilacijom na visokoj temperaturi prevodi u visoko aktivni THC-izomer. Drugi parcijalni metod za sintezu THC-a u cilju povećanja potentnosti prirodnog THC-a je acetilacija, jer je tada skoro tri puta aktivniji. $\Delta^{9} \mathrm{THC}$, poznatiji kao "Superhaš", dobiva se parcijalnom sintezom THC-a. Prosječna koncentracija $\Delta^{9} \mathrm{THC}-\mathrm{a}$ u hašišu je oko $10 \%$ (na američkom tržištu $6 \%$ ), u ulju hašiša 15$30 \%$. Puši se na vodenu lulu ili se cigareta ili džoint natopi sa par kapi ulja (14).

Efekti ovih tvari se izražavaju se putom endokrinog, kardiovaskularnog i imunosustava. Dolazi do promjene raspoloženja, uznemirenosti, euforije asocirane s lošom percepcijom vremena uz nekontrolirani smijeh, pospanost i apatiju. Oni koji prvi put probaju ove tvari mogu osjetiti anksioznost, paniku, kao i paranoju koja može perzistira i po nekoliko dana. $\Delta^{9} \mathrm{THC}$ je topiv u lipidima i brzo dospijeva do mozga i drugih tkiva. Potom se pretvara u svoj aktivni meta-bolit 11-hidroksi-THC, a oba imaju relativno dug poluživot (50 sati). Zbog njihove rapidne distribucije u masne stanice, duljina trajanja efekata smanjuje se na par sati. A9THC blokira otpuštanje Gonadotropni-oslobađajućeg hormona, koji je preko hipotalamusa odgovoran za oslobađanje luteinizirajućeg i folikulostimulirajućeg hormona. To kod muškaraca uzrokuje smanjenje kvaliteta i kvantiteta ejakulata, a kod žena povećava razinu prolaktina. Osim hormonskih poremećaja smanjuje se i otpornost organizma na infekcije (3).

\section{FENICIKLIDINSKI ANALOG - KETAMIN}

Ketamin je klasificiran kao disocijativan anestetik, uzrokuje disocijativne epizode s osjećajem fragmentacije uz smanjene reaktibilnosti na bol i okoliš. Još se legalno proizvodi za uporabu u veterinarskoj i dječjoj kirurgiji kao anestetik. Prvi put je proizveden 1965. na univerzitetu u Michigan-u. Po kemijskoj je građi srodan fenilciklidinu. Rekreativno korištenje ketamina vjerojatno počinje 60 -ih i od tada mu popularnost kontinuirano raste (27). Moguće je da se u početku počeo koristiti kao dodatak tabletama ecstasy-ja (28). Nakon 70-ih Ketamin postaje popularan na partijima, dok ga pojedinci uzimaju u namjeri da poboljšaju spiritualna putovanja. Ketamin je komercijalno dostupan u tekućem stanju pakiran u bočice od po $10 \mathrm{ml}$. Tekuća forma se lako prevodi u prah kako se najčešće prodaje, često pomiješan sa $B_{12}$ vitaminom. Može se uzimati ušmrkavanjem, oralno, može se pušiti zajedno sa marihuanom ili duhanom, a u najpotentnijoj formi se miješa sa vodom i injektira. Rekreativna doza je oko $0.4 \mathrm{mg} / \mathrm{kg}$ a anestetička doza je oko $0,8 \mathrm{mg} / \mathrm{kg}$. $\mathrm{LD}_{50}$ je skoro 30 puta veća od anestetičke doze. Nakon I.V. ili I.M. uporabe ima visoku dostupnost dok se nakon oralne primjene slabije resorbira i prolazi intenzivan metabolizam prvog prolaza. Metabolizira se u jetri gdje se preko intermedijarnih spojeva prevodi u hidrosolubilnu formu i izlučuje urinom. Nakon injiciranja počinje djelovati za oko 5 minuta, intranazalno za oko 10 min, glavni disocijativni efekti nastaju oko 10 minuta kasnije. Vrijeme poluživota je oko 2 sata. Pri manjim dozama nastaju analgezični efekti dok pri većim dozama nastaje amnezija (29).Pri kroničnom korištenju se razvija tolerancija.

Ketamin djeluju izravno ili neizravno na brojne transmitorske sustave. Primarno djeluje kao nekompetentivan potentan NMDA antagonist, inhibira djelovanje glutamata na receptore što ima za rezultat blokadu protoka kalcija kroz kanale $(30,31)$. Na NMDA receptore, koji imaju važnu ulogu u neurokemiji ponašanja i procesiranju senzornih informacija, se veže na isto mjesto za koje se veže i PCP. Subanestetičke doze ketamina dovode do kognitivnih poremećaja, perceptualnih smetnji, i drugih smetnji 
koje se javljaju i kod shizofrenije (32). Ketamin djeluje na različitim drugim receptorima u mozgu kao što su kolinergički i opioidni, djeluje inhibitorno na ponovnu pohranu norepinefrina, dopamina i serotonina $(33,34)$. NMDA blokada dovodi do pojačanog lučenja dopamina u međumozgu i prefrontalnom korteksu i do aktivacije serotoninskog sistema specifično pogađajući $5-\mathrm{HT}_{1 \mathrm{~A}}$ receptore $(35,36)$.

Svojim djelovanjem na NMDA receptore ketamin dovodi do promjena u percepciji i kognitivnim funkcijama u više područja mozga, većina učinaka je ovisna o dozi (37). Manje doze dovode do povišenog raspoloženja, derealizacije, depersonalizacije, vidnih halucinacija, ugodnih ili neugodnih snova, poremećaja pažnje i memorije te poremećaja koordinacije $(38,39)$. Pri uobičajenom doziranju ketamin iskrivljuje senzorne stimule dovodeći do iluzija (40). Veće doze imaju duže i intenzivnije djelovanje, izazivaju povraćanje, dizartričan govor, amneziju, poremećenu sliku tijela i okoline, paranoidne sumanutosti, negativizam, agresivnost, delirijum, poremećaje motornih funkcija i agitaciju $(41,42)$. Visoke doze korisnici opisuju kao vantjelesna ili iskustva tik do smrti.Ova tzv. vantjelesna iskustva traju oko 1 sat, a percepcija vremena je značajno izmijenjena (43). Korisnici opisuju osjećaj vječnosti, osjećaj disociranosti od samog sebe, osjećaju da lebde iznad vlastitog tijela. Djelovanje se postepeno smanjuje tijekom slijedećeg sata. Ketamin dovodi do stanja sedacije, imobilnosti, analgezije i amnezije. Vidni poremećaji ili flaschback-ovi se mogu javljati danima ili tjednima nakon izloženosti ketaminu.

Kardiovaskularno toksično djelovanje je posljedica centralne ekscitacije simpatikusa i manifestira se hipertenzijom, tahikardijom i palpitacijama. Djelovanje na dišni sustav uključuje depresiju disanja do apnee. Povećana razina kateholamina u cirkulaciji dovodi do bronhodilatacije, nađene su masivni edemi pluća nakon smrti uzrokovane intoksikacijom ketaminom. Korisnici na ovu drogu ponekad reagiraju katatonijom, ukočenim izrazom lica sa otvorenim ustima, fiksiranim ukočenim pogledom sa dilatiranim zjenicama i rigidnim držanjem. Stanje je karakterizirano socijalnom apstinencijom, autističnim ponašanjem, nemogućnošću održavanja kognitivnih funkcija, osiromašenimsadržajem misli i bizarnim reakcijama.

Kako je ova droga bez okusa, mirisa i boje može se kradom usuti u piće te koristiti za omamljivanje neopreznih žrtava u cilju seksualnog iskorištavanja. Uz gubitak svijesti žrtva može razviti anterogradnu amneziju već 15 min nakon ingestije. Vidne halucinacije, snovi i amnezija mogu otežati razlikovanje doživljaja nastalih djelovanjem droge od događaja koji su se stvarno dogodili čineći tako od žrtve nepouzdanog svjedoka na sudu (29).

Ne postoji specifičan antidot za intoksikaciju ketaminom te su zbog toga suportivne mjere i praćenje vitalnih funkcija glavni oblik liječenja. Zbog visokog terapeutskog indeksa jedino teško predoziranje predstavlja stvarni rizik morbiditeta i mortaliteta i zahtijeva liječenje u intenzivnoj skrbi. Pacijent može postati povučen, paranoidan i vrlo nekoordiniran. U takvim slučajevima je potrebno simptomatsko liječenje. Miran i nestimulirajući okoliš je obično od najveće pomoći. Pacijenta je potrebno smjestiti u prostor sa najmanjom količinom svjetla i stimulacije. Neuroleptici se daju vrlo rijetko jer nuspojave koje izazivaju mogu dalje provocirati pacijenta. Ako je neophodno pacijentu se mogu dati benzodijazepini. Midazolam je sredstvo izbora u kontroli prateće anksioznosti.

\section{ZAKLJUČAK}

Sve veća dostupnost novih sintetičkih (dizajniranih) droga koje nisu kontrolirane međunarodnim ugovorima za suzbijanje zlouporabe droga predstavlja relativno novu pojavu na europskim tržištima droga. Takve se tvari, koje se obično proizvode izvan Europe, mogu nabaviti preko online trgovaca, u specijaliziranim trgovinama, a također se ponekad prodaju zajedno $s$ kontroliranim tvarima na ilegalnom tržištu droge. Današnje tržište droge je čini se protočnije i dinamičnije, i manje se bazira na biljnim tvarima koje se prevoze na velikim udaljenostima do potrošača na tržištima Europe. Globalizacija i razvoj informacijske tehnologije su važni pokretači. Razumijevanje ukupnih trendova u korištenju sintetičkih stimulativnih droga složeno je zbog činjenice da one često jedna drugu zamjenjuju, budući 
da potrošači donose odluke prema njihovoj dostupnosti, cijeni i percipiranoj "kvaliteti". Amfetamini i ecstasy su i dalje najčešće korišteni sintetički stimulansi u Europi i u određenoj mjeri se natječu s kokainom. S kontinuiranom pojavom novih psihoaktivnih tvari na tržište droga javlja se mogućnost da nove ili prikrivene tvari koje su pridonijele pojavi smrtnih slučajeva ostanu neotkrivene. I pored brojnih štetnih učinaka na zdravlje ovisnika i negativnih posljedica na njegovu okolinu popularnost novih sintetičkih droga raste i u njihovom sprečavanju potreban je timski rad u sklopu integralnog i multidiscplinarnog pristupa liječenja te potpora cjelokupnog društva i svih njegovih dijelova čije je to zadaća.

\section{LITERATURA}

1. Babić D i sur. Psihoaktivne tvari: duševni poremećaji i poremećaji ponašanja uzrokovani uporabom psihoaktivnih tvari. Mostar: Sveučilište u Mostaru. 2016.

2. Martinac M i sur. Prepoznavanje i liječenje trovanja sintetičkim „klupskim drogama“. Pediatria Croatica. Zagreb. 2003.

3. Leshner A. Club drugs community drug alert bulletin, National Institute on Drug Abuse. National Institute of Health. 2001.

4. Dimitrijević I. Sintetičke droge - novi trendovi upotrebe supstance. Beograd: Galeb. 2003.

5. Langston W.J, i sur. Chronic Parkinsonism in Humans Due to a Product of Meperidine-Analog Synthesis. Science, February 25th. 1993;12:30-7.

6. Jenkins R Synthetic panics-the symbolic politics of designer drugs. New York: New York University Press, 1999;2:36-48.

7. Clayton L. Designer drugs,revised edn. New York: Hazelden, 1998;25:307-18.

8. Robins P. Designer drugs. New York: Enslow Publishers. 1995.

9. Creighton FJ, Dawn L. Ecstasy psychosis and Flashbacks. Br J Psychiatry 1991;159:713715 .
10. Watson L, Beck J. Psychoactive Drugs. National Institutes of Health 1991;23:261.

11. Vasilj I. Nove sintetičke droge. U: Babić D. Psihoaktivne tvari. Sveučilište u Mostar., 2016.

12. Europski centar za praćenje droga i ovisnosti o drogama. Europsko izvješće o drogama. Trendovi i razvoj 2013.Luksemburg: Ured za službene publikacije Europske unije. 2014.

13. Europski centar za praćenje droga i ovisnosti o drogama. Europsko izvješće o drogama. Trendovi i razvoj 2014. Luksemburg: Ured za službene publikacije Europske unije. 2015.

14. Watson L, Beck J. New Age seekers: MDMA use as an adjunct to spiritual pursuit. J Psychoactive Drugs. 1986;23:261-270.

15. Downing J. The psychological and physiological effects of MDMA on normal volunteers. J psychoactive drugs 1986;18:335-339.

16. Valter K, Arrizabalaga P. Designer drugs directory. Amsterdam: Elsevier, 1998.

17. McCan U, Ricaurte G. Lasting neuropsychiatric sequelae of methylenedioximethamfetamine ("Ecstasy") in recreational users. J. ClinPsychopharmacol. 1991;11:302-305.

18. Creighton F.J. i sur. Ecstasy Psychosis And Flashbacks. Br J Psychiatry. 1991.

19. King GR, Ellinwood EH. Amphetamines and other stimulants- Baltimore: Williams and Wilkins. 1997;207-223.

20. Baggot M, Heifets B, Jones RT, Mendelson J, Sferios E, Zehnder J. Chemical analysis of ecstasy pills, JAMA.2000;248:2190.

21. Hatzidimitriou G, McCann UD, Ricaurte GA. Altered serotonin inervation patterns in the forebrain of monkeys treated with MDMA seven years previously: factors influencing abnormal recovery. J Neurosci1999;19:5096-5107.

22. Green A, Cross A, Goodwin G. Review of pharmacology and clinical pharmacology of 3,4-methylenedioximethamfetamine. Psychopharmacology. 1995;19:247-60. 
23. Liecthi ME, Baumann C, Gamma A, Vollenweider FX. Acute psychological effects of 3,4methylenedioximethamfetamine (MDMA; "Ecstasy") are attenuated by serotonin uptake inhibitor Citalopram. Neuropsychopharmacology. 2000;22:513-521.

24. Lester SJ, Baggot M, Welm S i sur. Cardiovascular effects of 3,4-methylenedioxymethamphetamine: a double-blind, placebo-controlled trial. Ann Intern Med. 2000;133:969973.

25. Garbino J, Henry JA, Mentha G, Romand JA. Ecstasy ingestion and fulminant hepatic failure: liver transplantation to be considered as the last therapeutic option. Vet Hum Toxicol 2001;43:99-102.

26. Schwartz RH, Milteer R, LeBeau MA. Drug-facilitated sexual assault ("date rape"). South Med J 2000;93;558-561.

27. Dotson J, Ackerman D, West L. Ketamine abuse. J Drug Issues 1995;25:751-757.

28. Jansen KLR. Nonmedical uses of ketamine. BMJ 1997;19;53-63.

29. Smith KM. Drugs used in acquaintance rape. J Am Pharm Assoc 1999;39;519-525.

30. Haas DA, Harper DG, Ketamine. A review of its pharmacologic properties and use in ambulatory anesthesia. Anesth Prog 1992;39:6168.

31. Hampton RY, Medzihradsky F, Woods JH i sur. Stereospecific binding of $3 \mathrm{H}$ Phencyclidine in brain membranes. Life Sci 1982;30:2147-2154.

32. Anand A, Charney DS, Oren DA i sur. Attenuation of the neuropsychiatric effects of ketamine with lamotrigine. Arch Gen Psychiatry 2000;57:270-276

33. Kohrs R, Durieux ME. Ketamine: teaching an old dog new tricks. AnesthAnalg. 1998;87;1186-1193.
34. Pap A, Bradberry CW. Excitatory amino acid antagonists attenuate the effects of cocaine on extracellular dopamine in the nucleus accumbens. J PharmacolExpTher 1995;274;127-133.

35. Bubser M, Keseberg U, Notz PK i sur. Differential behavioral and neurochemical effects of competitive and noncompetitive NMDA receptor antagonists in rats. Eur J Pharmacol 1992;229;75-82.

36. Loscher W, Honack D. Effects of the novel $5-\mathrm{HT}_{1 \mathrm{~A}}$ receptor antagonist, (+)-WAY 100135 on the stereotyped behavior induced by NMDA receptor antagonist dizocilpine in rats. Eur J Pharmacol1993;242:99-104.

37. Óye N, Paulsen O, Maurset A. Effects of ketamine on sensory perception: evidence for a role of $\mathrm{N}$-methyl D-aspartate receptors. J pharmacolExpTher1992;260:1209-1213.

38. Zacny JP, Galinkin JL. Psychotropic drugs used in anesthesia. Practice, abuse, liability and epidemiology of abuse. Anesthesiology 1999;90:269-288.

39. Moore KA, Kilbane EM, Jones ER i sur. Tissue distribution of ketamine in a mixed drug fatality. J Forensic Sci. 1997;2:1183-1185.

40. Garfield JM, Garfield FB, Stone JG i sur. A comparison of psychologic responses to ketamine and thiopental-nitrous oxide-halothane anesthesia. Anesthesiology 1994;36:329-338.

41. Malhotra AK, Pinals DA, Weingartner $\mathrm{H}$ i sur. NMDA receptor function and human cognition: the effects of ketamine in healthy volunteers. Neuropsychopharmacology 1996;14:301-307.

42. Krystal JH, Karper LP, Seibyl JP i sur. Subanesthetic effects of the noncompetitive NMDA antagonist, ketamine, in humans: psychometric, perceptual, cognitive, and neuroendocrine responses. Arch Gen Psychiatry. 1994;51:199-214.

43. Delgarno PJ, Shevan D. Illicit use of Ketamine in Scotland. J Psychoactive Drugs 1996;28:191-199. 


\title{
NEW SYNTHETIC (DESIGNER) DRUGS
}

\author{
Shpend Haxhibeqiri ${ }^{1}$, Valdete Haxhibeqiri ${ }^{2}$ \\ ${ }^{1}$ Kosovo Forensic Psychiatric Institute,University Clinical Centre of Kosovo, Pristina, Kosovo \\ ${ }^{2}$ Medical Biochemistry Clinic, University Clinical Centre of Kosovo, Faculty of Medicine - \\ University of Pristina, Kosovo
}

\begin{abstract}
In recent decades, numerous studies have shown an increase in the use of new synthetic drugs and the so-called "addictions without drugs" with a simultaneous decline in the use of opiates.Globalization and the development of information technology are significant drivers in this direction. Understanding the overall trends in the use of new synthetic drugs is complicated due to the fact that they often substitute for one another, whereas the consumers make decisions according to their availability, price and perceived "quality". Compounds of more potent pharmacodynamic properties are obtained by molecular modification of known drugs. They are produced in the form of powder, tablets, capsules, or solutions. They have a simulative or depressive effects and they are consumed orally, by inhaling powder through nostrils, by injection, or similar. Designer drugs have very unpleasant, even potentially lethal and unwanted effects.New synthetic (designer) drugs are our reality and the interest of society for these substances is increasing. Methamphetamine draws physicians' particular attentionbecause the users of these preparations more often come to intensive care units and this represents a major burden for the healthcare system. Although the penalties for the production and distribution of designer drugs are rigorous, this does not stop their further production and distribution. Constant growth in the number of designer drugs and their effects have led to the prevalence of new behavioral patterns related to the use of these substances. Since ecstasy launched the rave revolution, addicts are in the pursuit of new "super drugs". Despite many adverse effectson the individual's health and negative consequences on his environment, the popularity of new synthetic drugs is growing and their prevention requires team work within the integral and multidisciplinary approach to treatment and support of the entire society.

Key words: synthetic, designer, drugs
\end{abstract}

Correspondence:

ShpendHaxhibeqiri, MD, Psychiatrist

E-mail: dr.shpendhaxhibeqiri@gmail.com 